\section{PREVALENCE OF SEROLOGICAL INELIGIBILITY AMONG BLOOD donors of a Hemotherapy Center in Caxias do Sul, SOUTHERN BRAZIL}

\author{
Heloisa Ril ${ }^{1}$, Crislaine Aparecida Paludo ${ }^{1}$, Márcia Araújo Leite ${ }^{2}$, \\ Fernanda Cattani ${ }^{1}$
}

\begin{abstract}
Introduction: Blood donation should be voluntary, anonymous and altruistic, and the donor should not, directly or indirectly, receive any remuneration or benefit by virtue of donating blood. Like any other therapeutic method, transfusion procedures are not risk free and can expose the patient to a several complications. Serological screening is of great importance to ensure transfusion safety. The present study aimed to estimate the prevalence of serological ineligibility among blood donors from a Hemotherapy Center in Caxias do Sul (RS).

Method: An exploratory, descriptive and quantitative study was conducted on data from July 2010 to December 2015 collected at a Hemotherapy Center in Caxias do Sul (RS).

Results: During the study period, 14,267 blood donors attended the Hemotherapy Center, of which 9,332 (65.40\%) were males and 4,935 (34.60\%) were female. Considering only the suitable donors, 12,702 blood donations were performed, $144(1.13 \%)$ presented positive serological tests. The most prevalent positive serology was for hepatitis B (anti-HBc) with 98 cases $(0.77 \%)$, followed by syphilis with 19 cases $(0.15 \%)$; Chagas disease, with $10(0.08 \%)$; hepatitis C, with nine $(0.07 \%)$; and HIV and HTLV, with four $(0.03 \%)$ reactive samples each.
\end{abstract}

Conclusion: The results presented are important for health surveillance and make it possible to take measures to ensure safe blood stocks.

Keywords: Serology; blood donors; communicable diseases

Blood donation should be voluntary, anonymous, and altruistic; moreover, the donor should not, directly or indirectly, receive any remuneration, according to the current Brazilian legislation ${ }^{1}$. Hemotherapy is a therapeutic treatment consisting of blood transfusion or transfusion of blood products ${ }^{2}$. Blood donation should be performed by specialized professionals and must strictly fulfill several criteria to ensure blood transfusion safety. For example, donors must comply with certain mandatory requirements set forth by law, such as being from 16 to 69 years, 11 months, and 29 days of age, and providing written formal consent from the legal guardians of donor candidates aged 16 and 17 years for every blood donation. The maximum age threshold for first donation is 60 years, 11 months, and 29 days of age. The maximum frequency allowed is four blood donations per year for men and three donations per year for women, and the minimum interval between donations should be 2 months for men and 3 months for women. Additionally, donor candidate must weight at least $50 \mathrm{~kg}$ and have good health. Besides meeting these requirements, donor candidates must be assessed throughout the different stages of blood donation, including pre-screening, clinical screening, and serological screening. Blood donation in Brazil is regulated by Ordinance No.
Clin Biomed Res. 2017;37(1):11-17

1 Faculdade Cenecista de Bento Gonçalves (FACEBG). Bento Gonçalves, RS, Brazil.

2 Hemotherapy Center. Caxias do Sul, RS, Brazil.

Corresponding author: Heloisa Ril helo.ril@hotmail.com Faculdade Cenecista de Bento Gonçalves (FACEBG)

Rua Arlindo Franklin Barbosa, 460. 95708-514, Bento Gonçalves, RS, Brazil. 
158, dated of February 4, 2016, which determines the Sanitation Regulation for Hemotherapy Centers, which develop activities related to transfusion procedures and to the production cycle of human blood and blood components ${ }^{1,3}$.

The blood transfusion cycle starts with blood collection from donor candidates and continues with pre-screening, clinical screening, and laboratory screening. Reducing the possibility of transmitting infectious agents through blood transfusion requires measures to ensure its safety ${ }^{4}$. The current legislation establishes that all country's Hemotherapy Centers must perform serological tests to detect markers of hepatitis B (anti-HBc/HbsAg), hepatitis C (anti- HCV), syphilis (Venereal Disease Research Laboratory, VDRL), AIDS (anti-HIV 1 and 2/Western blot), HTLV (anti-HTLV I and II), and Chagas disease (immunoenzymatic assay, EIA) ${ }^{1}$.

A study of 60,211 blood donations performed in the Caxias do Sul Blood Bank, southern Brazil, from 2001 to 2005 found that $1,485(2.50 \%)$ of these donations were discarded due to serological ineligibility, with the most prevalent marker being anti-HBc $(1.67 \%)$, followed by VDRL $(0.65 \%)^{5}$. The disposal of these ineligible blood bags during screening leads to substantial but necessary costs to achieve transfusion safety. Therefore, serological screening of blood donors is extremely important to prevent the dissemination of blood transmitted infectious microorganisms.

The present study aimed to investigate the prevalence of serological markers of hepatitis $B$, hepatitis C, AIDS, HTLV I/II, syphilis, and Chagas disease among blood donors attending a Hemotherapy Center in Caxias do Sul, southern Brazil, from July 2010 to December 2015.

\section{METHODS}

An exploratory, descriptive and quantitative study was conducted at a Hemortherapy Center in Caxias do Sul, southern Brazil. Firstly, the institution's database was searched for data on donor candidates with positive screening for the selected markers from July 2010 to December 2015. Subsequently, data were organized using Microsoft Office Excel 2007 for the creation of graphs and tables.

\section{RESULTS}

From July 2010 to December 2015, 14,267 donor candidates attended the Hemotherapy Center in Caxias do Sul, southern Brazil, of which 9,332 $(65.40 \%)$ were male and $4,935(34.60 \%)$ were female. Of the total number of candidates, 14,242 underwent clinical screening to ensure recipient's safety, of which 13,217 (92.80\%) were considered clinically eligible for blood donation and 1,025 (7.20\%) were considered ineligible.

Eligible candidates had their blood collected, 12,702 of which donated a full blood bag and had their blood samples screened for serological markers. Of the 12,702 donations, 12,558 were released for transfusion (serologically eligible) and 144 (1.13\%) were discarded (serologically ineligible). The most prevalent positive serology was for hepatitis B (anti-HBc and $\mathrm{HbsAg}$ ), with 98 cases $(0.77 \%)$; followed by syphilis (VDRL), with 19 cases $(0.15 \%)$; Chagas disease (EIA), with 10 cases $(0.08 \%)$; hepatitis $\mathrm{C}$ (anti-HCV), with nine cases $(0.07 \%)$; and HIV (anti-HIV 1 and 2/Western Blot) and HTLV (anti-HTLV I and II), with four (0.03\%) positive samples each (table 1). The findings presented in Figure 1 showed that, during the study period, the prevalence of hepatitis $B$ among blood donors significantly increased over the years.

Table 1: Annual distribution of positive results for serological markers in an Hemotherapy Center.

\begin{tabular}{|c|c|c|c|c|c|c|c|}
\hline $\begin{array}{c}\text { Positive } \\
\text { serological } \\
\text { screening }\end{array}$ & $\begin{array}{c}2010 \\
794(100 \%)\end{array}$ & $\begin{array}{c}2011 \\
1778(100 \%)\end{array}$ & $\begin{array}{c}2012 \\
2027(100 \%)\end{array}$ & $\begin{array}{c}2013 \\
2718(100 \%)\end{array}$ & $\begin{array}{c}2014 \\
2782(100 \%)\end{array}$ & $\begin{array}{c}2015 \\
2606(100 \%)\end{array}$ & $\begin{array}{c}\text { TOTAL } \\
\text { n (\%) }\end{array}$ \\
\hline $\begin{array}{l}\text { Chagas } \\
\text { disease (EIA) }\end{array}$ & $0(0.0 \%)$ & $3(0.17 \%)$ & $4(0.20 \%)$ & $2(0.07 \%)$ & $0(0.0 \%)$ & $1(0.04 \%)$ & $10(0.08 \%)$ \\
\hline $\begin{array}{l}\text { Anti-HBc / } \\
\text { HbsAg }\end{array}$ & $2(0.25 \%)$ & $3(0.17 \%)$ & $15(0.74 \%)$ & $22(0.80 \%)$ & $22(0.80 \%)$ & $34(1.30 \%)$ & $98(0.77 \%)$ \\
\hline Anti-HCV & $0(0.0 \%)$ & & & & $0(0.0 \%)$ & $2(0.08 \%)$ & $9(0.07 \%)$ \\
\hline $\begin{array}{l}\text { Anti-HIV } 1 \text { and } \\
\text { 2/Western Blot }\end{array}$ & $0(0.0 \%)$ & $3(0.17 \%)$ & $0(0.0 \%)$ & $1(0.04 \%)$ & $0(0.0 \%)$ & $0(0.0 \%)$ & $4(0.03 \%)$ \\
\hline Anti-HTLV I/II & $0(0.0 \%)$ & $0(0.0 \%)$ & $1(0.05 \%)$ & $1(0.04 \%)$ & $0(0.0 \%)$ & $2(0.08 \%)$ & $4(0.03 \%)$ \\
\hline VDRL & $0(0.0 \%)$ & $1(0.05 \%)$ & $1(0.05 \%)$ & $3(0.11 \%)$ & $5(0.18 \%)$ & $9(0.34 \%)$ & $19(0.15 \%)$ \\
\hline Total & $2(0.25 \%)$ & $13(0.73 \%)$ & $25(1.23 \%)$ & $29(1.06 \%)$ & $27(0.97 \%)$ & $48(1.84 \%)$ & $144(1.13 \%)$ \\
\hline
\end{tabular}

EIA: Immunoenzymatic assay; Anti-HBc: Detects the presence of the antibody against chorion (a protein that is present in the nucleus of the hepatitis B virus); HbsAg: Detects surface antigens of the hepatitis B virus; Anti-HCV: Detects the presence of antibodies against the hepatitis $C$ virus; Anti-HIV1 and 2: Detects the presence of antibodies against the HIV 1 and 2 viruses; Anti-HTLV I/II: Detects the presence of antibodies against the HTLV I/II viruses; VDRL: Veneral Disease Research Laboratory. A non-treponemal test to detect syphilis. 


\section{DISCUSSION}

Pretransfusion stages, such as donor's recruitment and selection, along with serological screening tests, reduce the possibility of transfusion transmission of infectious microorganisms but is not free of risk for recipients. During the study period, there was a higher prevalence of male donor candidates in the Hemotherapy Center in Caxias do Sul, southern Brazil, from July 2010 to December 2015. The lower prevalence of female candidates may be explained by the fact that some women do not reach the minimum weight for donating blood or by the occurrence of anemia in women during reproductive age and after the menstrual period, thus compromising attendance of women to the Hemotherapy Center ${ }^{4}$. Moreover, the higher prevalence in the male gender may be explained by the fact that current legislation establishes a maximum frequency of four donations per year for men and three donations per year for women ${ }^{1}$. Our results are consistent with those of a study that found a higher prevalence of male donors in the Caxias do Sul Blood Bank $(69.10 \%)^{5}$. In another study conducted in Maringá, southern Brazil, with 93,490 donor candidates, the percentage of male donors was $61.54 \%{ }^{6}$. Similarly, males accounted for $57.00 \%$ of blood donations performed in Porto Alegre, southern Brazil, from 2013 to $2014^{7}$.

The disposal rate is related to the importance of serological screening to prevent infectious disease transmission through blood transfusion. Hepatitis B, an infection transmitted by blood transfusion, is considered a public health problem, because of the high rates of serological disposals due to positive serological results ${ }^{8}$. In the present study, the overall disposal rate due to positive serological results was 144 donations $(1.13 \%)$, with markers for hepatitis B (anti-HBc) and syphilis (VDRL) being the most prevalent during the study period, as described in Table 1. These findings are in line with those of studies conducted in other Brazilian states and cities, as shown in Table 2 . In Porto Alegre, Brazil, the most prevalent positive serology among blood donor candidates was for hepatitis $B$, with $1,774(1.97 \%)$ cases in 2013 and 1,603 (1.82\%) in 2014, followed

Table 2: Comparison of seroprevalence among blood donors in different Hemotherapy Centers in Brazil.

\begin{tabular}{|c|c|c|c|c|c|}
\hline \multicolumn{6}{|c|}{ Serologically ineligible donors } \\
\hline & City/state & Blood donations & $\mathbf{N}$ & $\%$ & Authors \\
\hline \multirow{4}{*}{ Chagas Disease } & Caxias do Sul/RS & 12.702 & 10 & $0.08 \%$ & $*$ \\
\hline & Santa Maria/RS & 25.207 & 246 & $0.98 \%$ & Cogo et al. ${ }^{9}$ \\
\hline & Recife/PE & 204.124 & 31 & $0.02 \%$ & Sabino et al. ${ }^{10}$ \\
\hline & São Paulo/SP & 49.541 & 19 & $0.04 \%$ & Ferreira et al. ${ }^{11}$ \\
\hline \multirow{5}{*}{ Hepatitis B } & Caxias do Sul/RS & 12.702 & 98 & $0.77 \%$ & * \\
\hline & Alfenas/MG & 25.034 & 347 & $1.39 \%$ & Diogo et al. ${ }^{12}$ \\
\hline & Porto Alegre/RS & 88.201 & 1,603 & $1.81 \%$ & Trevizan and Cavada ${ }^{7}$ \\
\hline & Barra das Garças/MT & 1.607 & 91 & $5.66 \%$ & Delmondes et al. ${ }^{13}$ \\
\hline & Erechim/RS & 2.108 & 119 & $5.60 \%$ & Sbeghen and Paraboni ${ }^{14}$ \\
\hline \multirow{4}{*}{ Hepatitis C } & Caxias do Sul/RS & 12.702 & 9 & $0.07 \%$ & $*$ \\
\hline & Uberaba/MG & 218.871 & 814 & $0.37 \%$ & Josahkian et al. ${ }^{15}$ \\
\hline & Anápolis/GO & 13.633 & 12 & $0.09 \%$ & Costa et al. ${ }^{16}$ \\
\hline & Campo Mourão/PR & 25.044 & 96 & $0.38 \%$ & Alves and Isolani ${ }^{17}$ \\
\hline \multirow{4}{*}{ HIV } & Caxias do Sul/RS & 12.702 & 4 & $0.03 \%$ & * \\
\hline & Cruz Alta/RS & 280 & 15 & $5.4 \%$ & Martins et al. ${ }^{18}$ \\
\hline & Maringá/PR & 93.490 & 46 & $0.05 \%$ & Pereira and Bonafé \\
\hline & Pernambuco & 106.203 & 217 & $0.20 \%$ & Queiroz et al. ${ }^{19}$ \\
\hline \multirow{4}{*}{ HTLV } & Caxias do Sul/RS & 12.702 & 4 & $0.03 \%$ & * \\
\hline & Piauí/PI & 233.927 & 400 & $0.17 \%$ & Oliveira et al..$^{20}$ \\
\hline & Ceará & 679.610 & 164 & $0.02 \%$ & Gomes and Eleutério ${ }^{21}$ \\
\hline & Uberaba/MG & 147.489 & 36 & $0.02 \%$ & Lima et al. ${ }^{22}$ \\
\hline \multirow{5}{*}{ Syphilis } & Caxias do Sul/RS & 12.702 & 19 & $0.15 \%$ & $*$ \\
\hline & Cruz Alta/RS & 6.139 & 37 & $0.60 \%$ & Martins et al. ${ }^{18}$ \\
\hline & Goiás & 389.424 & 2,364 & $0.61 \%$ & Rodrigues $^{23}$ \\
\hline & Montes Claros/MG & 82.743 & 343 & $0.41 \%$ & Magalhães et al. ${ }^{24}$ \\
\hline & Porto Alegre/RS & 88.201 & 819 & $0.92 \%$ & Trevizan and Cavada ${ }^{7}$ \\
\hline
\end{tabular}

${ }^{*}$ Data found in this study. 
Ril et al.

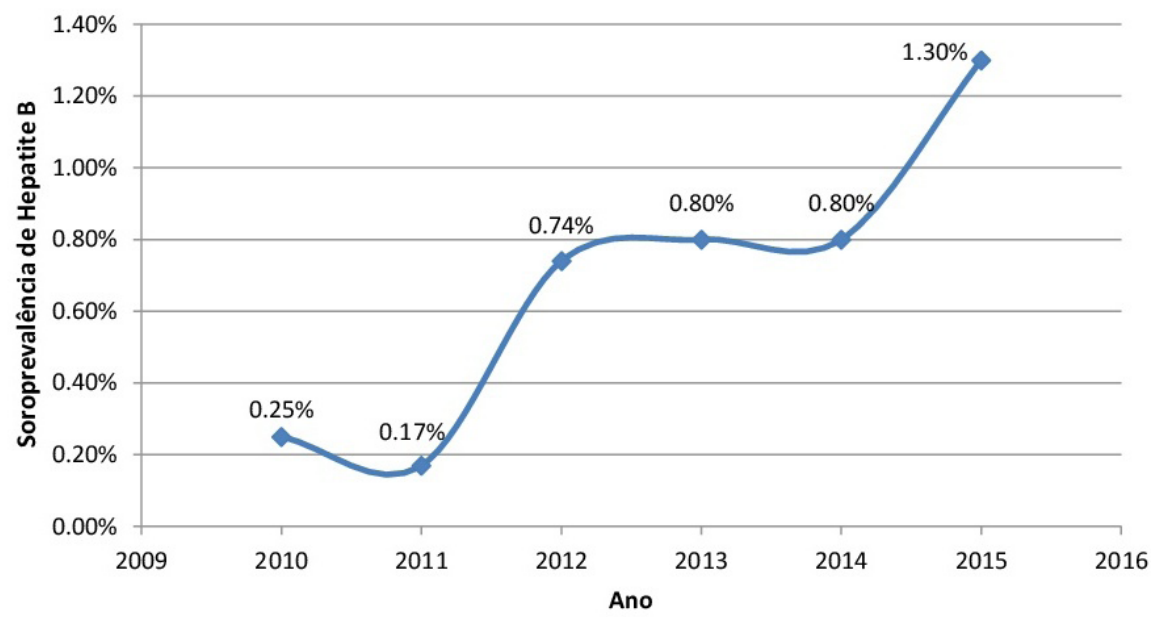

Figure 1: Annual prevalence of positive serology for hepatitis B markers.

by syphilis, with $702(0.78 \%)$ and $819(0.93 \%)$ cases respectively ${ }^{7}$. According to Ramos and Ferraz ${ }^{25}$, the most prevalent cases of serological ineligibility in the blood center of Campo Mourão, southern Brazil was due to hepatitis B, with $275(71.43 \%)$ donors, and syphilis, with 43 donors (11.17\%), out of a total of 385 disposals after serological screening.

In the present study, $98(0.77 \%)$ of blood donors had positive serology for hepatitis $B$. In Erechim, southern Brazil, the rate of positive serology for hepatitis $B$ was $5.6 \%$ out of a total of 2,108 blood donors ${ }^{14}$. In a survey of report forms of 25,034 blood donors from the Hemotherapy Center da Santa Casa de Alfenas (NHSCA), located in Alfenas, southeastern Brazil, Diogo et al. ${ }^{12}$ found $347(1,83 \%)$ positive results for the anti-HBc marker from January 2000 to December 2006. Data from the Fundação Hemoninas show that hepatitis $B$ is the main cause of serological ineligibility among blood donors, accounting for $1.26 \%$ of ineligible donations in serological screening ${ }^{26}$.

According to Hemoprod, the percentage of serological ineligibility due to hepatitis $\mathrm{B}$ among blood donors in Brazil was $1.47 \%$ in 2012, with each Brazilian region showing different seropositive rates. The northern region was the one with the highest prevalence of positive hepatitis B serology, with $3.77 \%$, followed by the southern region, with $1.94 \%$. In 2013 , the prevalence of the HBs-Ag marker in Brazil ranged from $0.07 \%$ in the state of Espírito Santo to $0.43 \%$ in the state of Paraíba. The state of São Paulo had the lowest rate for anti-HBc $(0.76 \%)$, whereas the highest rates were reported in the states of Rondônia $(4.38 \%)$ and Acre $(4.33 \%)^{27}$.

According to data from the Epidemiological Bulletin of the Brazilian Ministry of Health, there were 38,007 confirmed cases of hepatitis B from 1999 to 2011 in the southern region. In 990 (6.60\%) of these cases, blood transfusion transmission was reported as the possible source/mechanism of infection ${ }^{28}$. In an American study of 217,738 donors, the prevalence of positive hepatitis $B$ donors was 121 $(0.06 \%)^{29}$. The high rates of hepatitis $B$ and syphilis found in the present study may be explained by the current environmental risks, which mainly involve unprotected sex, since these two diseases may be sexually transmitted. Although there is a vaccine for hepatitis $B$, the number of individuals contaminated with HBV has increased, as shown in Figure 1. This may be explained by the fact that vaccination campaigns are not meeting population demands and that these individuals were infected before the hepatitis $B$ vaccine was available.

Syphilis is a chronic sexually transmitted infection caused by the Treponema pallidum spirochete. The usual source of infection is contact with a cutaneous or mucosal lesion of a sexual partner contaminated with syphilis, but it can also be transmitted during pregnancy and via blood transfusion ${ }^{30}$. In the present study, $19(0.15 \%)$ donors were positive for syphilis. In Brazil, syphilis is the second leading cause of serological ineligibility among blood donors, with a prevalence of $0.67 \%$. The northeastern region had the highest prevalence, with $0.97 \%$ of positive cases, followed by the southern region, with $0.67 \%$. The prevalence ranges of syphilis from $0.13 \%$ in the state of Rondônia to $2.42 \%$ in the state of Maranhão, with Rondônia presenting the lowest positivity rate for syphilis but the highest prevalence for the anti-HBc marker ${ }^{27}$.

Screening methods to detect syphilis include non-treponemal tests, such as the VDRL test, and diagnosis should be confirmed with treponemal tests such as the microhemagglutination assay for Treponema pallidum or the fluorescent treponemal 
antibody-absorption test ${ }^{1}$. A study assessing the prevalence of serological ineligibility due to syphilis in a Hemotherapy Center in Cruz Alta, southern Brazil, from 2003 to 2009 found $60(0.03 \%)$ VDRL positive cases out of a total of 20.780 medical records ${ }^{31}$. According to Rodrigues, there were 389,424 blood donations in the Goiás Blood Center, midwestern Brazil, from January 2002 to December 2011, 2,364 $(0.61 \%)$ of which were positive for the VDRL marker ${ }^{23}$. In the state of Santa Catarina, the seroprevalence of syphilis was 81.3 per 100,000 inhabitants $(0.08 \%)$ from January to December 201032. In Montes Claros, southeastern Brazil, positive results for the VDRL marker was the most prevalent reason for serological ineligibility, with $243(0.41 \%)$ cases out of a total of 82,743 blood donors ${ }^{24}$.

Chagas disease is known to be an endemic infection in some regions of South America and Brazil; therefore, serological screening of blood donors is essential, since this disease may be transmitted by blood transfusion. Chagas disease is an infection caused by the protozoan parasite Trypanosoma cruzi and transmitted by the infected stool of hematophagous triatomine insects. Other means of contamination include vertical transmission, oral transmission, and organ transplantation ${ }^{33}$. Currently, screening for Chagas disease in Hemotherapy Centers is performed by detecting anti-T.cruzi antibodies using EIA or chemiluminescence ${ }^{1}$. In the present study, positive serological results for Chagas disease were found in 10 donors $(0.08 \%)$. In 2012, serological ineligibility rate for blood donation due to Chagas disease was $0.26 \%$, according to data from the Annual Hemotherapy Production Bulletin. This bulletin also reports that the prevalence of Chagas disease in Brazil ranged from $0.02 \%$ in the state of Espírito Santo to $0.54 \%$ in the state of Rio de Janeiro ${ }^{27}$. In an analysis of 25,207 blood donations performed in the Hematology Unit of Hospital Universitário de Santa Maria, southern Brazil, from January 2004 to December 2007, Cogo et al. ${ }^{9}$ found that $246(0.98 \%)$ donors presented a positive or indeterminate serology for Chagas disease. The prevalence of positive serology for Chagas disease may be explained by the higher number of individuals who had not sought other health care services yet and whose disease had not been detected before, since it is usually asymptomatic, by the high rate of migration from rural to urban areas, and by improvements in housing, educational, and health conditions $\mathbf{s}^{34,35}$.

Serological screening for hepatitis $\mathrm{C}$ is performed by two tests: detection of anti-HCV antibodies or combined detection of anti-HCV antibodies and HCV antigens; and detection of HCV nucleic acid ${ }^{1}$. In the present study, $9(0.07 \%)$ donors were positive for hepatitis C. In 2012, the ineligibility rate due to hepatitis $\mathrm{C}$ among blood donors was $0.27 \%$ in Brazil, ranging from $0.09 \%$ in the state of Tocantins to $0.65 \%$ in the state of Mato Grosso do Sul ${ }^{27}$.

There were 18,307 confirmed cases of hepatitis $C$ in the southern region from 1999 to 2011 . In 3,910 $(32.30 \%)$ of these cases, transfusion transmission was reported as the possible source/mechanism of infection ${ }^{28}$. Josahkiane et al. ${ }^{15}$ assessed 218,871 blood donations carried out at Hemocentro Regional de Uberaba (HRU) from 1995 to 2008, $814(0.40 \%)$ of which were ineligible because of positive serological test for HCV. The implementation of the nucleic acid amplification test in hemotherapy centers has been of great help in attempting to minimize risks arising from blood transfusions. This test is also mandatory for hepatitis $C$ screening, thus reducing the window period to 6 or 7 days $^{36}$.

In the present study, the prevalence of positive serology for HIV 1 and 2 and HTLV I and II was $0.03 \%$, which was the lowest prevalence among all the tested serologies. Currently, screening for HIV includes serological tests that detect the presence of the antibody against HIV or allow for the combined detection of antibody against HIV + HIV p24 antigens and molecular tests that aim to detect HIV nucleic acid ${ }^{1}$. From 1980 to 2015, 207 HIV cases were reported to the Notifiable Diseases Information System (Sistema de Informação de Agravos de Notificação, SINAN) as the possible source/mechanism of transfusion infection ${ }^{37}$. In 2012, $0.36 \%$ of blood donors were serologically ineligible due to HIV infection; in the southern region, this percentage was $0.28 \%{ }^{28}$. HTLV I and II are screened by detecting antibodies against HTLV I/II'. In Brazil, the prevalence of serological ineligibility due to positive serology for HTLV was $0.17 \%$ in 2012 , with the northeastern region showing the highest seropositive rate, with $0.28 \%$, and the northern region showing the lowest rate, with $0.07 \%{ }^{27}$.

There is clearly a significant difference in the prevalence of positive serologies among blood donors from different Brazilian states. One should bear in mind that variations in results may be explained by several factors, such as differences in the methodologies used and good clinical screening, because when the latter is efficiently performed donors with possible positive serology are disqualified for blood donation. In the present study, hepatitis B and syphilis were the main causes of serological ineligibility among blood donors and may be related to present-day habits and behaviors, which lead to increased risk of contamination. Therefore, pre-transfusion measures covering recruitment of blood donors, clinical screening, and serological screening are of great help in attempting 
to minimize risks arising from blood transfusions ${ }^{18}$. Considering that microorganisms causing diseases such hepatitis B, hepatitis C, HIV, HTLV, syphilis, and Chagas disease may be transmitted during transfusion and impair recipient's quality of life, further studies are necessary to evaluate the serological profile of blood donors. Screening to detect the presence of a given blood transmitted microorganism in blood bag will contribute to the adoption of more objective and early measures to reduce contamination during transfusion.

\section{Acknowledgements}

We would like to thank Professors Fernanda Cattani and Crislaine Aparecida Paludo for their guidance during research and Márcia Araújo Leite, responsible for the Hemotherapy Center, for approving and supporting this study.

\section{Conflicts of interest}

The authors declare no conflicts of interest

\section{REFERENCES}

1. Brasil. Portaria $n^{\circ} 158$, de 4 de fevereiro de 2016. Redefine o Regulamento Técnico de Procedimentos Hemoterápicos. Diário Oficial da União. 2016.

2. Vizzoni AG. Fundamentos e técnicas em banco de sangue. São Paulo: Érica; 2015.

3. Brasil. Resolução RDC $n^{\circ} 51$, de 7 de novembro de 2013. Altera a Resolução RDC n 57 , de 16 de dezembro de 2010, que determina o Regulamento Sanitário para Serviços que desenvolvem atividades relacionadas ao ciclo produtivo do sangue humano e componente $e$ procedimentos transfusionais. Diário Oficial da União. 2013.

4. Azevedo AS, Nogueira CS, Artiles CB, Domingues CF, Alves CN, Malheiros GC, et al. Fatores da triagem clínica que impedem a doação de sangue. Revista Científica da FMC. 2015;10:711.

5. Rodrigues DM, Lara GM, Lazzarotto AR, Michelin LM, Fracasso J, Lovatel $R$, et al. Prevalência de marcadores sorológicos no Banco de Sangue de Caxias do Sul. Revista Panama Infectologia. 2008;3:32-5.

6. Pereira GC, Bonafé SM. Soroprevalência para doenças infectocontagiosas em doadores de sangue na cidade de Maringa/Paraná. Revista Uningá. 2015;44:16-24.

7. Trevizan H, Cavada CA. Uma abordagem situacional dos serviços de hemoterapia da cidade Porto Alegre/RS. Vigil Sanit Debate. 2016;4:35-43.

8. Ottoni LC, Zwielewski GT, Jandotti AC, Riguete RC, Mella-Júnior SE, Kaiser CC, et al. Soroprevalência do descarte de bolsas de sangue em um Núcleo de Hemoterapia de Três Lagoas - MS. Iniciação Científica CESUMAR. 2013;15:177-88.

9. Cogo JP, Foletto A, Monteiro JB, Pereira KN, Ribeiro MC, Segala $Z$, et al. Perfil epidemiológico de doadores de sangue soropositivos para Doença de Chagas na Região Sul. Saude. 2014;40:125-32.

10. Sabino EC, Salles NA, Saar M, Barreto AM, Oikawa M, Oliveira $\mathrm{CD}$, et al. Enhanced classification of Chagas serologic results and epidemiologic characteristics of seropositive donors at three large blood centers in Brazil. Transfusion. 2010;50:2628-37.

11. Ferreira JC Fo, Costa PI, Buainain A, Rosa JÁ. Soropositividade para doença de Chagas entre doadores de sangue em Araraquara, Estado de São Paulo, no período de 2004 a 2008. Rev Soc Bras Med Trop. 2011;44:110-2.

12. Diogo FV, Souza VA, Diogo FL, Chavasco JK. Estudo da soroprevalência da infecção pelo vírus da hepatite $B$ entre os doadores de sangue do Núcleo Hemoterápico da Santa Casa de Alfenas (Alfenas/MG) por meio do marcador anti-HBc. Rev Bras Pesq Saude. 2012;14:59-64.

13. Delmondes PH, Claro HR, Scherer EF. Marcadores sorológicos da Hepatite B em doadores de sangue do Hemocentro de Barra do Garças/MT. Rev Interdisciplinar. 2014;11:29-33.

14. Sbeghen MD, Paraboni ML. Prevalência da reatividade ao $\mathrm{AntiHBc}$ total em candidatos a doação de sangue, submetidos a pré-triagem sorológica pelo Vírus da Hepatite B no Município de Erechim/RS. Perspectiva. 2010;34:165-72.
15. Josahkian JA, Lima GM, Eustáquio JM, Martins RA, Soares S, MoraesSouza $\mathrm{H}$, et al. Prevalência de inaptidão sorológica pelo vírus HCV em doadores de sangue no Hemocentro Regional de Uberaba (MG), Fundação Hemominas. Rev Patol Trop. 2010;39:261-71.

16. Costa AG, Moraes PB, Cruvinel KP, Stival MM, de Lima RM. Incidência de Hepatite $\mathrm{C}$ em doadores de sangue no município de Anápolis no ano de 2010. Universitas. 2013;11:11-7.

17. Alves AS, Isolani AP. Soroprevalência de Hepatite $\mathrm{C}$ em doadores de sangue do Município de Campo Mourão-PR. SaBios. Rev Saude e Biol. 2013;8:13-8.

18. Martins AP, Silva B, Dal Molin DB Mendes GA. Soroprevalência de doenças infecciosas em doadores de sangue do Hemocentro regional de Cruz Alta-Rio Grande do Sul. Clin Biomed Res. 2015;35:211-6.

19. Queiroz NM, Sampaio DA, Santos ES, Bezerra AC. Modelo logístico na determinação de fatores associados à infecção HIV em doadores de sangue na Fundação HEMOPE. Rev Bras Hematol Hemoter. 2012;34:217-21.

20. Oliveira EH, Silva FL, Silva ML. Perfil epidemiológico dos doadores de sangue infectados pelo vírus HTLV I/II, no Estado do Piauí. Rev Interdisciplinar. 2015;8:149-56.

21. Gomes FV, Eleutério J Jr. HTLV II em doadores de sangue na Hemorrede do Ceará - HEMOCE. Rev Assoc Med Bras. 2011;57:316-8.

22. Lima GM, Eustáquio JM, Martins RA, Josahkian JA, Pereira GA, Moraes-Souza H, et al. Declínio da prevalência do HTLV-1/2 em doadores de sangue do Hemocentro Regional 
da Cidade de Uberaba, Estado de Minas Gerais, 1995 a 2008. Rev Soc Bras Med Trop. 2010;43:421-4.

23. Rodrigues MA. Soroprevalência de Sífilis em doadores de sangue do Hemocentro de Goiás no período de 2002 a 2011 [monograph]. Anápolis (GO): Universidade Estadual de Goiás; 2012.

24. Magalhães TA, Teles LF, Nacimento JE, Oliveira LM, Xavier EM, Aguiar KM. Prevalência de inaptidão sorológica em doadores de sangue no hemocentro regional de Montes Claros, Minas Gerais. Rev Pesqui Cuid Fundam. 2016;8:4864-71.

25. Ramos VF, Ferraz FN. Perfil epidemiológico dos doadores de sangue do Hemonúcleo de Campo Mourão-PR no ano de 2008. SaBios. Rev Saude Biol. 2010;5:14-21.

26. Silva SM, Oliveira MB, Martinez EZ. Distribution of serological screening markers at a large hematology and hemotherapy center in Minas Gerais, Southeastern Brazil. Rev Bras Hematol Hemoter. 2016;38:206-13.
27. Brasil. Terceiro Boletim Anual de Produção Hemoterápica. Brasília: Agência Nacional de Vigilância Sanitária; 2013.

28. Brasil. Boletim Epidemiológico Hepatites Virais. Brasília: Ministério da Saúde; 2012.

29. Sheik MY, Atla PR, Ameer A, Sadig A, Sadler PC. Seroprevalence of Hepatitis B and C infections among Healthy Volunteer Blood Donors in the Central California Valley. Gut Liver. 2013;7:66-73.

30. Kumar V, Abbas AK, Aster JC. Robbins patologia básica. 9th ed. Rio de Janeiro: Elsevier; 2013.

31. Boff D, Lunkes DS, Kunzler A, Rohr JI. Prevalência de VDRL reagente em doadores do hemocentro regional de Cruz Alta - RS, Brasil, no período de 2003 a 2009. Rev Patol Trop. 2011;40:179-84.

32. Saraiva SS. Perfil sorológico e demográfico dos doadores de sangue do estado de Santa Catarina, no período Janeiro e Dezembro de 2010 [dissertation]. Florianópolis (SC): Universidade Federal de Santa Catarina; 2011.

33. Neves DP, Melo AL, Linardi PM, Vitor RW. Parasitologia humana. 12th ed. São Paulo; 2011.

34. Oliveira MF, Nagao-Dias AT, Pontes VM, Souza AS Jr, Coelho HL, Coelho IC. Tratamento etiológico da doença de chagas no Brasil. Rev Patol Trop. 2008;37:209-28.

35. Moraes-Souza H, Ferreira-Silva MM. O controle da transmissão transfusional. Ver Soc Bras Med Trop. 2011;44(Suppl 2):64-7.

36. Azevedo DR. Importância da introdução do NAT (NucleicAcid Test) HIV/HCV nos serviços de hemoterapia do Brasil [monograph]. Brasília (DF): Universidade Católica de Brasília; 2014.

37. Brasil. Ministério de Saúde. Boletim epidemiológico HIV-AIDS. Brasília (DF): Ministério da Saúde; 2013.

Received: Nov 28, 2016 Accepted: Mar 30, 2017 